\title{
Smooth transition from grid to standalone solar diesel mode hybrid generation system with a battery
}

\author{
Aya M. Elsherbiny ${ }^{1}$, Adel S. $\mathrm{Nada}^{2}$, Mohammed Kamal ${ }^{3}$ \\ 1,2,3 Departement of Electrical power Engineering, Al-Azhar University, Egypt \\ ${ }^{1}$ New Damietta Higher Institute for Engineering \& Technology, Egypt
}

\begin{tabular}{l}
\hline Article Info \\
\hline Article history: \\
Received Mar 26, 2019 \\
Revised Apr 20, 2019 \\
Accepted Jul 21, 2019 \\
\hline
\end{tabular}

Keywords:

Hybrid AC/DC microgrid MATLAB/Simulink Incremental conductance MPPT

PID controller

\begin{abstract}
This paper described a self-supply smart microgrid which may be a low voltage or medium voltage distribution network. It considered an efficient energy system in which different renewable sources as photo-voltaic array, wind, or conventional as diesel generator, and storage called distributed generators which organized to chance the load power demand at any time with reliability. It can operate either on-grid or off-grid configuration, especially limited areas far from the utility grid needed another backup power. By using Matlab/Simulink, a solar PV system is modeled, simulated, and determined the characteristic of a particular photovoltaic cell panel under the influence of different values of ambient conditions. Taking into consideration MPPT algorithm which increases the solar energy efficiency by Incremental conductance technique to track MPP correctly with fast response. Power electronic DC/DC converter and DC/AC inverter are used with PWM technique. To compensate the power fluctuations of the system under different possible transient cases, a high performance control based on an improved virtual synchronous generator is added to confirm smooth variants in voltage, frequency and active power during transient conditions. The results show the PV/Diesel generator/battery/power/frequency and voltage performance at two different conditions.
\end{abstract}

Copyright (c) 2019 Institute of Advanced Engineering and Science. All rights reserved.

\section{Corresponding Author:}

Mohammed Kamal,

Departement of Electrical power Engineering,

Al-Azhar University,

Al Mokhayam Al Daem, Egypt.

Email: mKalshaear@yahoo.com

\section{INTRODUCTION}

The traditional power grid utilizes fossil fuels as its primary sources of energy which cause dust emissions, climate change, carbon dioxide, and continuous shortage of fossil fuels. But recently, renewable energy sources (RESs) based distributed generation (DG) units are preferred cause its several advantages such as flexible extensibility, environmental-friendliness, high efficiency and improved reliability. Consequently, the hybrid microgrid concept is also suggested to overcome the defects caused by the individual application due to its flexibility and efficiency. It's very important for faraway areas to build up a complete system able to meet their need demands and overcome disconnected from the utility grid with high efficiency and stability. So, this research will present a proposed hybrid power generation system which useful to this applications and discuss in details.

Microgrid (MG) is a building block of a distributed system that combines storage, loads, traditional and renewable sources. It has two states: firstly, 'off-grid configuration' to generate and hand out power across isolated remote areas during discontinuity or any interrupting from the utility grid. Secondly where the system is able to give-and-take power from the grid is named 'grid-connected configuration'. The performance of a MG is very important during switching mode. Where MG is responsible to adjust 
the voltage and frequency without any support from the utility grid during the transient cases [1-4]. PV module can used as the fundamental power transformation unit of a PV generator system where its output characteristic depends on the solar insulation and the cell temperature [5-9]. Because PV module has nonlinearity characteristics, its design essentially modeled and simulated through maximum power point tracking (MPPT) [5]. Usually MPPT symbolizes by a power electronic circuit which offers an interface between PV and load by using some methods as Neural Network [5], Incremental Conductance (IC) [10], Fuzzy Logic [11], Perturb \& Observe [12], and Cuckoo search algorithm [13]. IC is commonly implemented and tracked control strategy because of its environmental adaptability and higher steady-state accuracy [14]. MPPT is applied in the boost converter by a Simulink/model where the duty cycle (D) is automatically varied uses IGBT with fast switching speed and low output impedance to generate the needed voltage to extract maximum power [3]. The DC/DC converters can be fixed the output voltage by changing duty cycle of transistors. It can be used separately for each source or used as a single DC/ DC converter for whole system [15]. The synchronous machine is one of the most important part of the power grid, diesel engine governor system, its reference and measured speed, mechanical power, voltage regulator and excitation system [16-19]. Energy storage system (ESS) is used as an auxiliary source [20].

In this study, the PV panel and diesel generator are used as the main power generator in the system. And due to the continuous demand for energy, ESS devices are required to compensate the power in case the load demand is less. Section 2 represented the whole system configuration. Section 3 showed the simulation of the proposed hybrid power system and results under different possible transient cases as switching from grid-connected to islanded with various dynamic loads. Finally, section $4 \& 5$ outlines results discussion and conclusion of the paper.

\section{SYSTEM CONFIGURATION}

This system composed of main items as PV, Diesel generator, battery, and dynamic load. The whole components are interconnected as shown in Figure 1 then discussed in details.

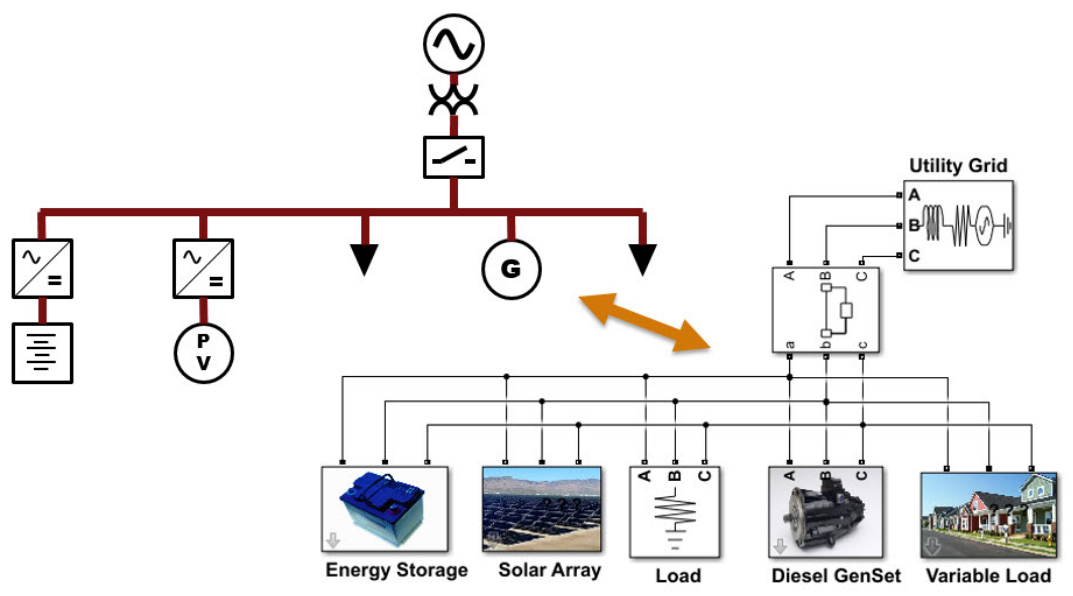

Figure 1. Single line diagram of proposed hybrid system

\subsection{PV system}

The basic device of a PV system is the PV cell which directly converts sunlight into DC electrical energy. Cells can be collected to form panels or arrays and modules for higher power applications. In order to PV cell has a nonlinear voltage-current (V-I) characteristic, it can be modeled using current sources, diodes and resistors. Several methods have been developed to model a PV panel as mathematical modeling and software/simulation. Single-diode and double-diode models are commonly used to simulate PV characteristics but one diode model equivalent circuit is popular model used to evaluate the performance data which are represented by P-V characteristic curves [21]. An ideal single-diode model in Figure 2(a) has three components: photo-current source, diode parallel to source, output current. In Figure 2(b) because the shunt resistance $R_{\text {sh }}$ is large, so it usually can be neglected then practical model simply added series resistance $\mathrm{R}_{\mathrm{s}}$ [14]. In Figure 2(c) practical model with series resistance $\mathrm{R}_{\mathrm{s}}$ and shunt resistance $\mathrm{R}_{\mathrm{sh}}$ is selected to

Int J Pow Elec \& Dri Syst Vol. 10, No. 4, Dec 2019 : 2065 - 2075 
simulate the behavior of a PV panel, through mathematical modeling [7]. Sun Power SPR-305E-WHT-D solar panel provides higher efficiency and performance than conventional designs and thin film solar panels. So, it saves both time and money and commonly used [4].

\subsubsection{Mathematical model of $P V$}

Case (a): neglecting the internal losses of the Current, by applying Kirchhoff's law:

$$
\begin{aligned}
& I=I_{p h}-I_{d} \\
& I_{d}=I_{O}\left[\exp \left(\frac{v}{\text { A.Ns.Vt }}\right)-1\right] \\
& V_{t}=K \cdot T_{C} / q
\end{aligned}
$$
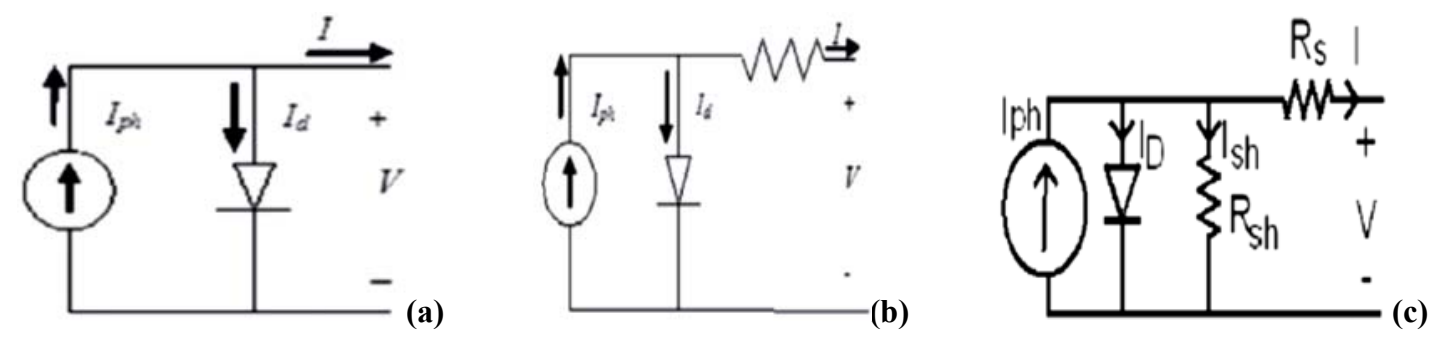

Figure 2. The equivalent circuit of PV device, (a) Ideal single diode model

(b) Practical model with $\mathrm{R}_{\mathrm{s}}$ (c) Practical model with $\mathrm{R}_{\mathrm{s}}$ and $\mathrm{R}_{\mathrm{sh}}$

Where $I$ is the output current, $I_{p h}$ is the photo current, $I_{d}$ is the diode current which proportional to the saturation current, $I_{O}$ is the reverse saturation or leakage current of the diode $(\mathrm{A}), V$ is the voltage imposed on the diode, $V_{t}$ is called the thermal voltage because of its exclusive dependence of temperature, $T_{C}$ is the actual cell temperature $(\mathrm{K}), K$ is Boltzmann constant $\left(1.381 \times 10^{-23} \mathrm{~J} / \mathrm{K}\right), q$ is charge of electron $\left(1.602 \times 10^{-19} \mathrm{C}\right)$, and Ns is the number of PV cells connected in series. $A$ is the ideality factor which depends on PV cell technology. Case (b): neglect series resistance $\mathrm{R}_{\mathrm{s}}$ and shunt resistance $\mathrm{R}_{\mathrm{sh}}$ due to their effect on the efficiency of the PV cell and module. When $\mathrm{R}_{\mathrm{s}}$ only is taken into consideration the equation will be as the next form [6].

$$
\mathrm{I}_{\mathrm{d}}=\mathrm{I}_{\mathrm{O}}\left[\exp \left(\frac{\mathrm{v}+\mathrm{Rs} \mathrm{I}}{\mathrm{A} \cdot \mathrm{Ns} \cdot \mathrm{Vt}}\right)-1\right]
$$

Case(c): where $R_{s}$ is the sum of several structural resistances in the solar cell and $R_{\text {sh }}$ represents the leakage effect of the solar cell semiconductor material [5]. By applying Kirchhoff's law:

$$
\begin{aligned}
& I=I_{p h}-I_{d}-I_{s h} \\
& I=I_{p h}-I_{O}\left[\exp \left(\frac{v+R s I}{\text { A.Ns.Vt }}\right)-1\right]-\left(\frac{\mathrm{v}+\text { Rs I }}{\text { Rsh }}\right)
\end{aligned}
$$

Solar cells are arranged in series and/or parallel in PV modules to obtain higher values of voltages and currents as shown in Figure 3. It can be realized that the number of series modules $\left(\mathrm{N}_{\mathrm{ser}}\right)$ is directly proportional to the equivalent series and parallel resistance and the number of parallel modules $\left(\mathrm{N}_{\mathrm{par}}\right)$ is inversely proportional to them. So, the output voltage is increased regularly with number of modules connected in series where the current remain unaffected. Similarly the voltage stay unchanged where the output current is improved proportionally to number of modules connected in parallel [11]. The equation for array using $\mathrm{N}_{\mathrm{ser}} \& \mathrm{~N}_{\mathrm{par}}$ is given by:

$$
I=I_{p h} N_{p a r}-I_{O} N_{p a r}\left[\exp \left(\frac{v+R s\left(\frac{N s e r}{N p a r}\right) I}{A . N s . V t}\right)-1\right]-\left(\frac{\mathrm{v}+\mathrm{Rs}\left(\frac{\text { Nser }}{\mathrm{Npar}}\right) \mathrm{I}}{\operatorname{Rsh}\left(\frac{\mathrm{Nser}}{\mathrm{Npar}}\right)}\right)
$$




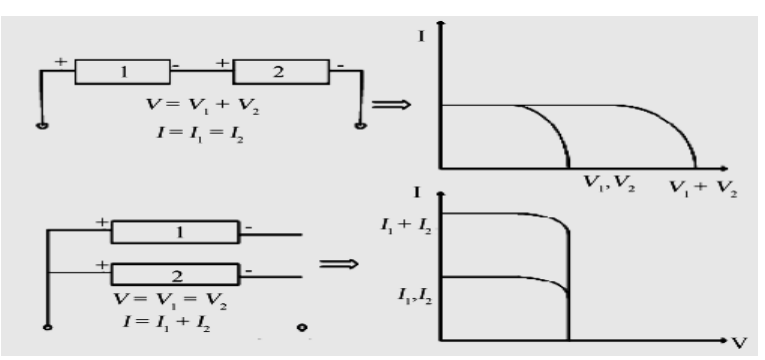

Figure 3. Series \& parallel connection on I-V characteristics [8]

\subsubsection{Effect of ambient conditions on $I-V \& P-V$ characteristics of $P V$}

Power output of PV module is directly proportional to solar radiation. Selecting the best location is essential to install PV module and the strength of solar radiation need to be considered. Besides that, local climate and environmental factors such as temperature, wind, and humidity need to be observed as it has an effect on the output power of PV module. Where the performance of PV module depend on the quantity of solar radiation and the temperature of surrounding. Figure 4 is showed $\mathrm{I}-\mathrm{V}$ and $\mathrm{P}-\mathrm{V}$ characteristics in case of varying irradiation with constant temperature. When irradiation increases, the current increases obviously but voltage output increases slightly. This results increasing in output power in this operating condition. In Figure $5 \mathrm{I}-\mathrm{V}$ and $\mathrm{P}-\mathrm{V}$ characteristics under varying temperature and constant irradiation. When the operating temperature increases, the current output rises marginally but the voltage output decreases drastically. This indicates a net drop in power output with increase in temperature [9].
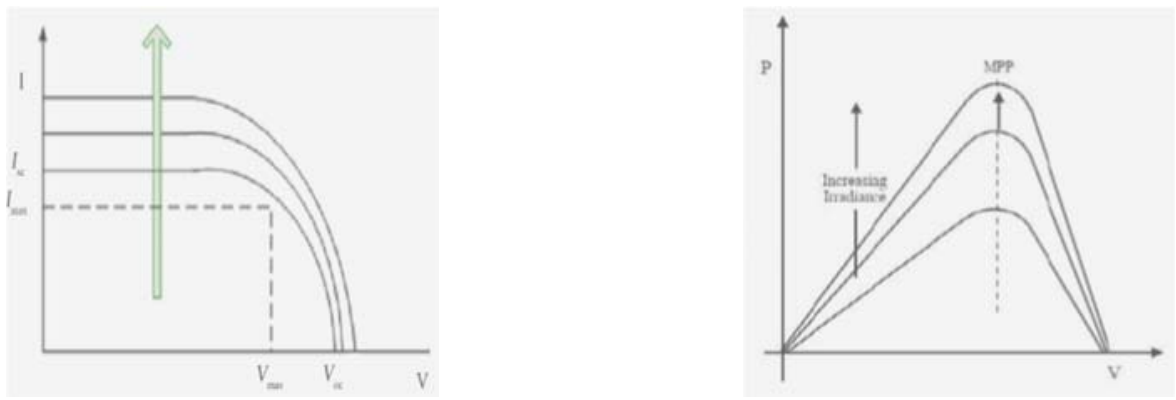

Figure 4. I-V and $\mathrm{P}-\mathrm{V}$ characteristics under varying irradiation $[8,10]$
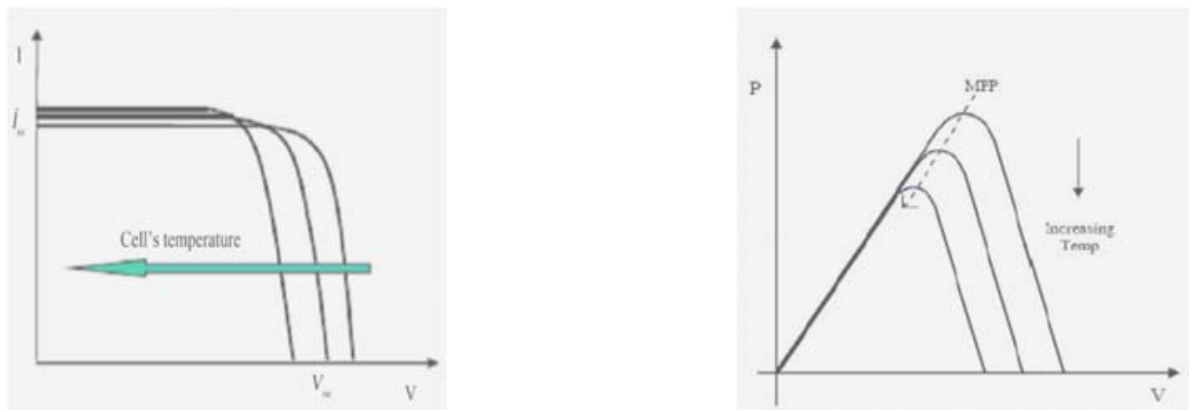

Figure 5. I-V and $\mathrm{P}-\mathrm{V}$ characteristics under varying temperature $[8,10]$

\subsubsection{Maximum power point tracking (MPPT)}

For maximizing the PV conversion efficiency, MPPT is implemented. MPPT is not a mechanical tracking but at the same time it can be used with a mechanical tracking system. MPP does not lie at 
a particular point but it moves around P-V curve depends on light intensity and temperature as Figure 6(a). IC is the most commonly method due to its better performance, faster tracking time and has no oscillation [12]. The principle of IC is achieved when the slope of the P-V curve is zero at the MPP, positive at the left of the MPP, and negative at the right of the MPP. By comparing the instantaneous conductance $(\mathrm{I} / \mathrm{V})$ to the incremental conductance $(\Delta \mathrm{I} / \Delta \mathrm{V})$, MPP can be found [22]. This algorithm shown in Figure $6(\mathrm{~b})$ is based on the principle that the MPP is reached when $(d P / d V=0)[14]$.

$$
\begin{gathered}
\frac{\mathrm{dP}}{\mathrm{dV}}=\frac{\mathrm{d}(\mathrm{V} . \mathrm{I})}{\mathrm{dV}}=\mathrm{I} \frac{\mathrm{dV}}{\mathrm{dV}}+\mathrm{V} \frac{\mathrm{dI}}{\mathrm{dV}}=\mathrm{I}+\mathrm{V} \frac{\mathrm{dI}}{\mathrm{dV}}=0 \\
\frac{\mathrm{dI}}{\mathrm{dV}}=-\frac{\mathrm{I}}{\mathrm{V}} \quad \text { Then } \mathrm{Vp}=\mathrm{Vmpp} \\
\text { When } \frac{d P}{d V}<0, \frac{d I}{d V}<-\frac{I}{V} \quad \text { Then } \mathrm{Vp}>\mathrm{Vmpp} \text { right to MPP, } \\
\text { When } \frac{d P}{d V}>0, \frac{d I}{d V}>-\frac{I}{V} \quad \text { Then } \mathrm{Vp}<\mathrm{Vmpp} \text { left to MPP }
\end{gathered}
$$

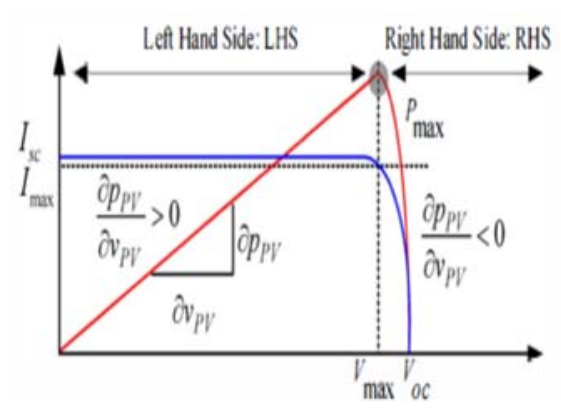

(a)

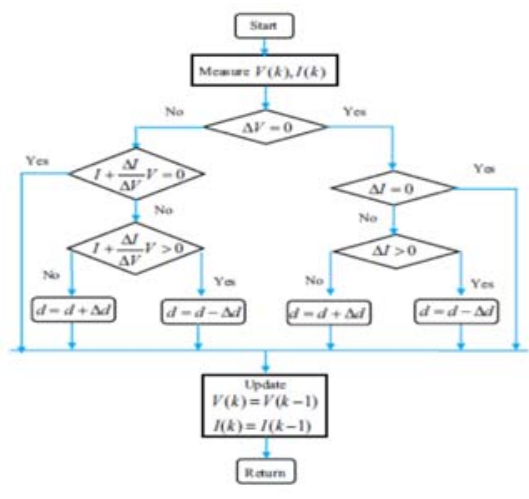

(b)

Figure 6. (a) Basic idea of IC method on a I-V \& P-V Curve (b) Flowchart of the basic IC algorithm

\subsubsection{Boost converter}

In generally, PV systems used DC/DC converters step up or step down the PV voltage and automatically varying the duty cycle (D) in order to generate the required voltage to accesses maximum power [3]. A boost converter is also named a step up converter because the output voltage is higher than the input voltage. As a result to achieve power balance, the output current is lower than the input current [23]. The dc voltage is essentially regulated through the DC/DC converter to fix the output capacity and determined the microgrid total power output [2]. The duty ratio of the chopper is increased linearly with increase in cell temperature and therefore the intensity [11]. The input-output voltage relationship for continuous conduction mode is given by:

$$
\frac{\mathrm{Vo}}{\mathrm{Vi}}=\frac{1}{1-\mathrm{D}}, \frac{1}{1-\mathrm{D}}>1, \text { for } \mathrm{D} \in(0,1)
$$

\subsubsection{Inverter}

In grid-connected PV systems; converting the DC output of the solar modules to AC power through the inverter is important to connect with utility and supplying local loads. Current-controlled H-bridge PWM inverter with low-pass output filters is the most common control structure for the DC/AC grid converter [24]. The DC/AC converters insert sinusoidal current into the grid controlling the power factor. Inverter controller confirm the control of active and reactive power generated to the grid, thus the control of DC-link voltage is achieved with high quality of the injected power and grid synchronization [3]. PWM is a technique which the switched voltage pulses are produced for different output frequencies and voltages. A distinctive modulator produces an average voltage value equal to the reference voltage within each PWM period. PWM provides a way to decrease the Total Harmonic Distortion (THD) of load current. THD requirement can be met when the output of a PWM inverter is filtered [23]. 


\subsection{Diesel generator (DG)}

In nuclear power plants especially, DG is one of the fundamental instruments needed to modeled and analyzed dynamically. Due to its critical function as a backup source to enable the MG performance in safe under transient conditions and its role in frequency and voltage regularity. Initially DG is in standby mode and delivering no active power. The plant is fed by the distribution network and the synchronous machine (SM) operates as a condenser to keep the bus voltage at 1.0 p.u.

\subsubsection{Governor}

Initially the governor and its design parameters are observed to set at steady state value 'zero' and the reference mechanical power also observed from no speed deviation scenario. This assumption when machine at the initialization state and changed directly once coming into the practical state [16]. It has two input terminals; one is the reference speed and another is the actual speed and one output terminal is the mechanical power $(P m)$. This produced $P m$ is fed into the synchronous generator block. The shaft speed that sensed from the generator block is fed back to the diesel engine block and the difference (error) between the reference and actual speed is measured and controlled with help of suitable PID controller which minimize the speed error. The actuator gets signal from governor to adjust the fuel injection rate which maintains the constant frequency output from the system [17]. The transfer function and the feedback loop of the modeled governor is shown in Figure 7.

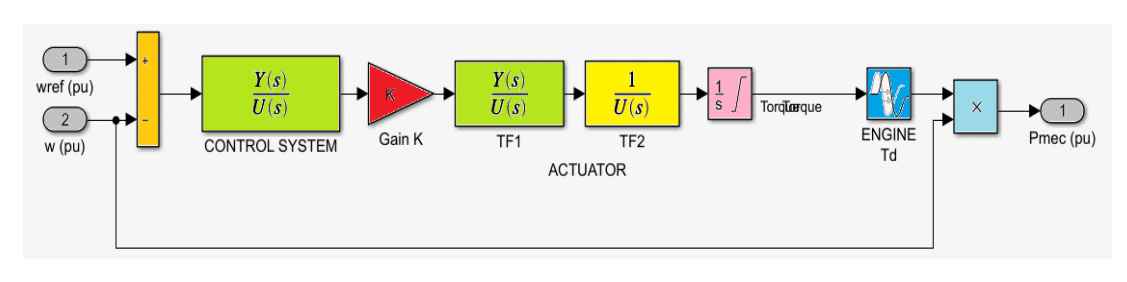

Figure 7. Simulink model of diesel engine governor

\subsubsection{Exciter}

The presence of exciter is very important in any generator because of its ability to control the field and terminal voltages during normal and abnormal situations. Also a role in voltage instability by controlling active and reactive power in generator [16]. Automatic Voltage Regulator (AVR) system is controlled the excitation current by using the terminal voltage error as a control input in the excitation control loop and so the generator output voltage is continuously detected until this error becomes zero [18]. Generator's excitation control is a typical non-linear time-variant control system that implements a SM voltage regulator and exciter based on the IEEE type AC1A excitation system model. Its output is the field voltage (Vf) which considered an input to SM block. The voltage waveform of the isolated grid is generated by the SM and its AVR controls the voltage during the two modes of operation [19].

\subsection{Energy storage system}

In practice, any type of batteries can be used in RESs such as lead-acid, nickel-cadmium, and nickeliron batteries and practically found that the most usually used in RESs is the deep-discharge lead-acid battery [15]. This type is preferred because of its advantages including the performance, price and battery lifetime. This design is prepared to provide small amounts of power over long periods continuously and its discharge up to $80 \%$ of the total battery capacity without damaging the battery [20]. Lead-acid batteries is presumed an electrochemical storage for this standalone DC microgrid taking into consideration its relatively low cost and matured technology. In order to protect the batteries from over-recharging and over-discharging, the batteries $\mathrm{SOC}_{\mathrm{B}}$ is limited between $\mathrm{SOC}_{\mathrm{B}_{-} \mathrm{MAX}}$ and $\mathrm{SOC}_{\mathrm{B}_{-} \text {MIN }}$ as upper and lower limitation respectively, as shown in (10) [1].

$$
\mathrm{SOC}_{\mathrm{B}_{-} \mathrm{MIN}} \leq \mathrm{SOC}_{\mathrm{B}}(\mathrm{t}) \leq \mathrm{SOC}_{\mathrm{B}_{-} \mathrm{MAX}}
$$

The temperature is a main factor for battery performance. Another important factor that characterizes the battery behavior is the state of charge (SOC) of a battery [25]. Often SOC is equivalent to a fuel gauge for a battery freight and its units are symbolized by a percentage points (i.e., $0 \%$ is empty, and $100 \%$ is full). There is a substitute form of the same measure that called the depth of discharge (DOD), and equal to one minus the SOC (i.e., $100 \%$ is empty, $0 \%$ is full). The SOC is commonly used to signify 
the current state of a battery in use and when discussing the lifetime of the battery after repeated use, the DOD is most often used [20].

\subsection{Load}

The load used in this paper is $500 \mathrm{kw}$ as a constant load at grid-connected mode and a variable load that initially $100 \mathrm{kw}$ resistive load and then variant into $300 \mathrm{kw}$. This load inserted in simulation at islanded mode with step time 10s approximate. The inverter converts the DC input from the PV module or the battery depending on the mode of operation into AC voltage with RMS value of $3500 \mathrm{~V}$.

\section{SIMULATION OF PROPOSED HYBRID POWER SYSTEM}

All the elements of the simulated system which shown in Figure 8 are connected to one module through the point of common coupling (PCC). Matlab/Simulink is used to gain results in different conditions either grid- connected mode or islanded mode. System's frequency is set at $50 \mathrm{~Hz}$ and operates in gridconnected mode before $4 \mathrm{~s}$ then the MG is disconnected from the utility at $4 \mathrm{~s}$. The frequency and voltage during transition mode are regulated to be constant just minimum droop at this moment. This droop is improved by using PID controller on the power of the battery depend on the difference between reference and actual speed of the governor. This method is proposed and results are taken with PID and without to compare the performance of the system in different parameters. Also when the load changes during the islanding mode, all the DGs react promptly to stabilize the system and match the load automatically.

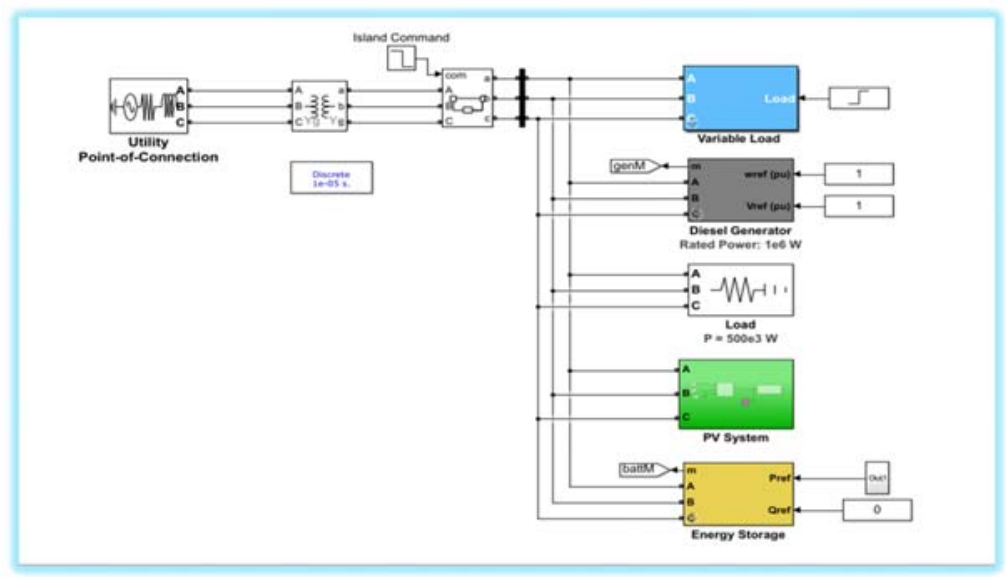

Figure 8. Simulink model of proposed hybrid power system

\subsection{MPPT under constant temperature and variant irradiance}

By using signal builder in Figure 9 to test the model at $\left(\mathrm{T}=25^{\circ} \mathrm{C}, \mathrm{Ir}=(400,600,800,1000) \mathrm{w} / \mathrm{m}^{2}\right)$. The output waveforms are shown in Figure 10.
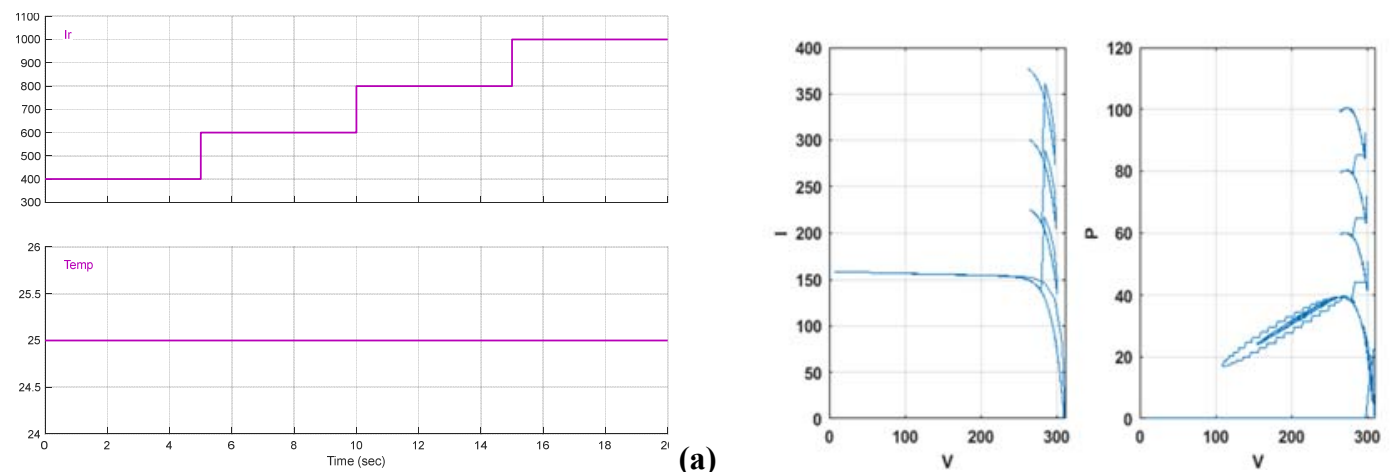

Figure 9. (a) Temp \& Ir profiles, (b) I-V \& P-V solar module $\mathrm{Ch}^{\mathrm{c}}$

Smooth transition from grid to standalone solar diesel mode ... (Aya M. Elsherbiny) 

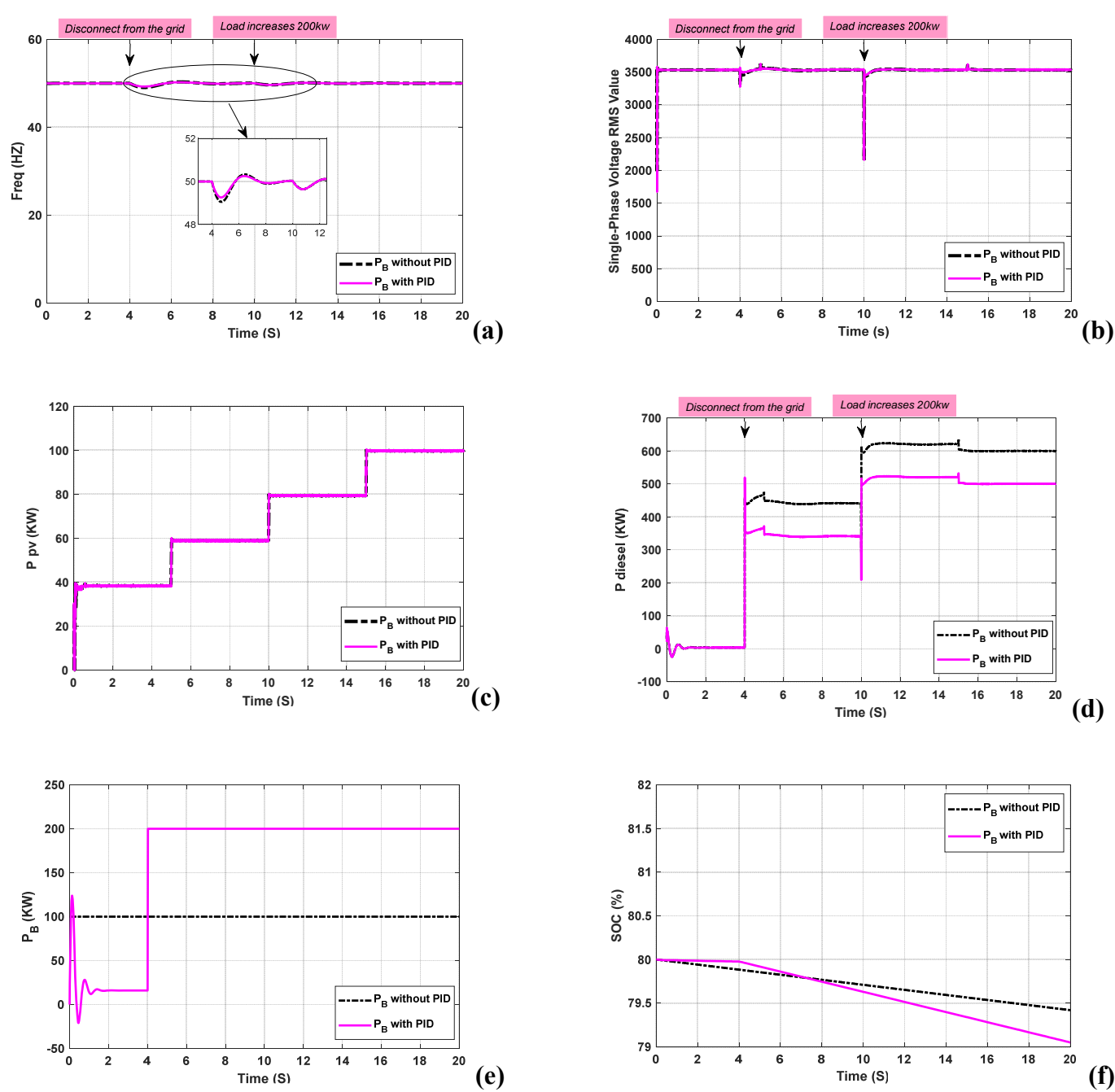

Figure 10. Simulation results at two conditions when $\mathrm{T}=25^{\circ} \mathrm{C}$, (a) Microgrid frequency,

(b) Microgrid phase voltage, (c) PV power, (d) Diesel power, (e) Battery power, (f) Battery state of charge

\subsection{MPPT under constant irradiance and variant temperature}

By using signal builder in Figure 11 to test the model at $\left(\mathrm{Ir}=1000 \mathrm{w} / \mathrm{m}^{2}, \mathrm{~T}=(25,30,35,40)^{\circ} \mathrm{C}\right)$. The output waveforms are shown in Figure 12.
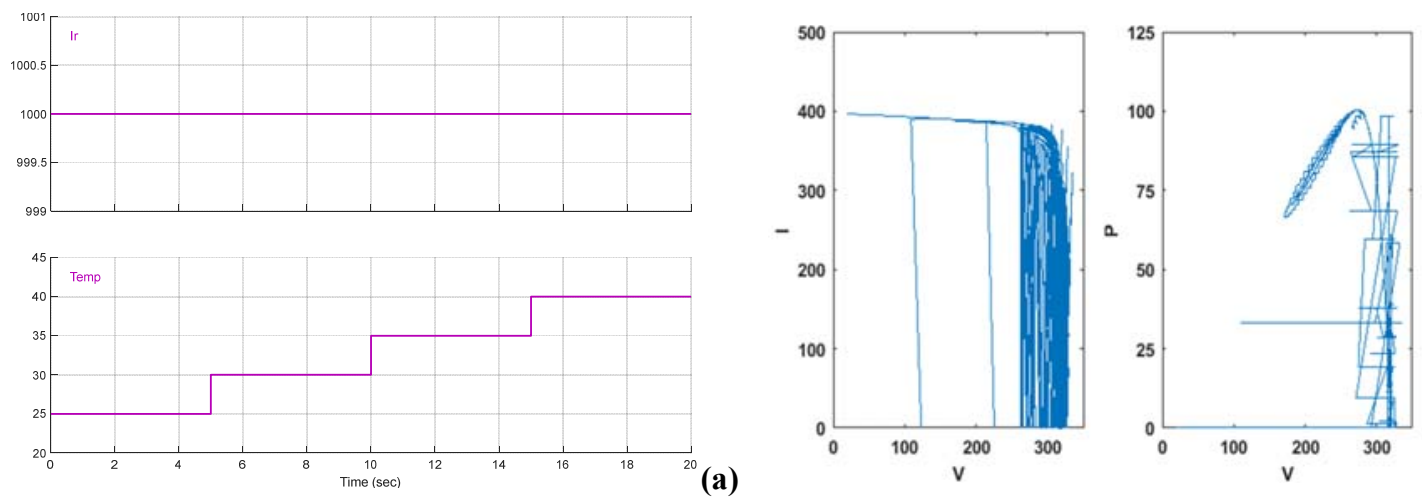

(b)

Figure 11. (a) Temp \& Ir profiles, (b) I-V \& P-V solar module $\mathrm{Ch}^{\mathrm{c}}$ 

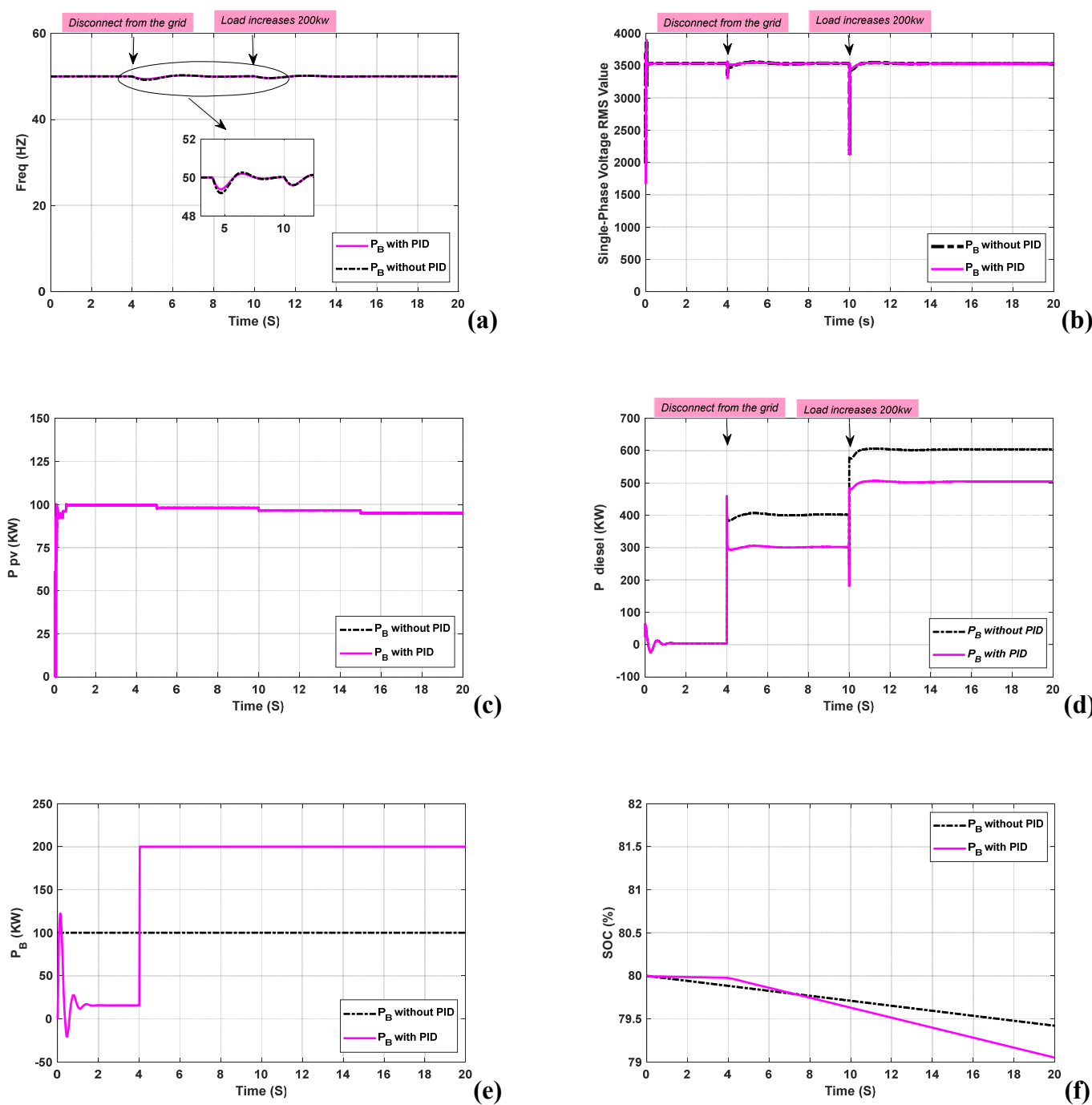

Figure 12. Simulation results at two conditions when $\mathrm{Ir}=1000 \mathrm{w} / \mathrm{m}^{2}$, (a) Microgrid Frequency, (b) Microgrid Phase Voltage, (c) PV power, (d) Diesel power, (e) Battery power, (f) Battery state of charge

\section{RESULTS DISCUSSION}

MPPT is achieved step-by-step until reached $100 \mathrm{kw}$ by using IC method under different ambient conditions whoever increasing temperature from $25: 40^{\circ} \mathrm{C}$ or irradiance from $400: 1000 \mathrm{w} / \mathrm{m}^{2}$ as showed in Figure 9(b) \& 10(b). The proposed Matlab/Simulink is proved that when irradiance is increased, PV power is increased frequently as showed in Figure 11(c). Also when temperature is increased, PV power is decreased as showed in Figure 12(c). I-V and P-V charachteristics of PV are showed at constant temperature and variant irradiance and vice versa. Modeling is compared that when adding PID controller to ESS, thus the results indicated that the performance of whole system is better than without PID connection. This is very clear in frequency, voltage, SOC, diesel power and battery power waveforms. Microgrid frequency is keeped constant at $50 \mathrm{HZ}$ with a small droop at discontinuity from the utility grid at step time $4 \mathrm{~s}$ approximate and when load is increased $200 \mathrm{kw}$ at step time $10 \mathrm{~s}$ approximate. Also microgrid phase voltage is regulated at 3500RMS value with higher drop when load is increased, but adding PID controller is reduced this drop. This achieved smooth transitions through the proposed system and new addition of PID to stabilize the system and match the load automatically specially when the load changes during the islanding mode. So all the DGs are reacted promptly. Initially DG is in standby mode and delivering no active power then it is increased its power when dicontinuity from the grid and when load is increased to compansate whole required power of demand. But adding PID is reduced its generated power that's clearly in in Figure 10(d) \& 12(d). Also battery power when using PID is produced $200 \mathrm{kw}$ to meet the need demand as diesel power is reduced. Its SOC 
slope performance is reduced within time when adding PID controller as showed in Figure 10(f) \& 12(f) which keep it long lifetime.

\section{CONCLUSION}

This paper is introduced a study of hybrid power generation system included renewable energy sources and conventional which has two operation modes; grid-connected and isolated system. The solar PV system is modeled and simulated using Matlab/Simulink to study the influence of different ambient conditions. Also, Diesel generator and storage is organized to chance the load power demand. The obtained results are confirmed stability of the system though voltage and frequency of MG in different transient cases. This proposed method is validated as effective, feasible and easy to implement and can be developed in the future to serve remote places. This research has a future vision to advance the proposed system with other subgrids to develop a fixed multi microgrid system able to work under transient cases with high efficiency.

\section{ACKNOWLEDGEMENTS}

The authors are grateful to the referees for their valuable suggestions.

\section{REFERENCES}

[1] C. Yin, H. Wu, F. Locment, and M. Sechilariu, "Energy Management of DC Microgrid Based on Photovoltaic Combined with Diesel Generator and Supercapacitor," Energy Conversion and Management, vol. 15, no. 132, pp. 14-27, 2017.

[2] J. Liu, MJ. Hossain, J. Lu, FH. Rafi, and H. Li, "A hybrid AC/DC Microgrid Control System Based on a Virtual Synchronous Generator for Smooth Transient Performances," Electric Power Systems Research, vol. 30, no. 162, pp.169-182, 2018.

[3] S. Gaurav, C. Birla, A. Lamba, S. Umashankar, and S. Ganesan, "Energy Management of PV-battery Based Microgrid System," Procedia Technology, vol. 1, no. 21, pp. 103-111, 2015.

[4] J. Hu, Y. Shan, Y. Xu, and JM. Guerrero, "A coordinated Control of Hybrid AC/DC Microgrids with PV-windbattery under Variable Generation and Load Conditions," International Journal of Electrical Power \& Energy Systems, vol. 1, no. 104, pp. 583-592, 2019.

[5] S. Assahout, H. Elaissaoui, A. El Ougli, B. Tidhaf, and H. Zrouri, "A Neural Network and Fuzzy Logic based MPPT Algorithm for Photovoltaic Pumping System," International Journal of Power Electronics and Drive Systems (IJPEDS), vol. 9, no. 4, pp. 1823-1833, 2018.

[6] H. Bellia, R. Youcef, and M. Fatima, "A detailed Modeling of Photovoltaic Module Using MATLAB," NRIAG Journal of Astronomy and Geophysics, vol. 3, no. 1, pp. 53-61, 2014.

[7] O. Nzimako, and R. Wierckx, "Modeling and Simulation of A grid-integrated Photovoltaic System Using a Realtime Digital Simulator," IEEE Transactions on Industry Applications, vol. 53, no. 2, pp. 1326-1336, 2016.

[8] SB. Asghar, and RK. Singh, "Simulink Based Analysis and Realization of Solar PV System," Energy and Power Engineering, vol. 7, no. 11, pp. 546-556, 2015.

[9] XH. Nguyen, and MP. Nguyen, "Mathematical Modeling of Photovoltaic cell/module/arrays with Tags in Matlab/Simulink," Environmental Systems Research, vol. 4, no. 1, pp. 24, 2015.

[10] K. Visweswara, "An investigation of Incremental Conductance Based Maximum Power Point Tracking for Photovoltaic System," Energy Procedia, vol. 1, no. 54, pp. 11-20, 2014.

[11] G. Balasubramanian, and S. Singaravelu, "Fuzzy Logic Based Controller for a Stand-alone Hybrid Generation System Using Wind and Photovoltaic Energy," International Journal of Advances in Engineering \& Technology, vol. 3, no. 2, pp. 668-679, 2012.

[12] RI. Putri, S. Wibowo, and M. Rifa'I, "Maximum Power Point Tracking for Photovoltaic Using Incremental Conductance Method," Energy Procedia, vol. 1, no. 68, pp. 22-30, 2015.

[13] S. Obukhov, A. Ibrahim, and R. Aboelsaud, "Maximum Power Point Tracking of Partially Shading PV System Using Cuckoo Search Algorithm," International Journal of Power Electronics and Drive Systems (IJPEDS), vol. 10, no.2, pp. 1081-1089, 2019.

[14] S. Motahhir, A. El Ghzizal, S. Sebti, and A. Derouich, "Modeling of Photovoltaic System with Modified Incremental Conductance Algorithm for Fast Changes of Irradiance," International Journal of Photoenergy, 2018.

[15] Z. Rasin, and A. Jidin, " Design and Development of Grid-connected Quasi-Z-Source PV Inverter," International Journal of Power Electronics and Drive Systems (IJPEDS), vol. 9, no. 4, pp. 1989-2005,2018.

[16] S. Talpur, "Testing and Model Validation of Round Rotor Synchronous Generator (GENROU)," Renewable and Sustainable Energy Reviews, vol. 1, no. 80, pp. 880-887, 2017.

[17] G. Konar, AK. Singh, and N. Chakraborty, "Modeling and Simulation of Standalone Micro Hydro-diesel Hybrid Power Plant for Indian hilly region," Chennai Fourth International Conference on Sustainable Energy and Intelligent Systems, 2013, pp. 159-166.

Int J Pow Elec \& Dri Syst Vol. 10, No. 4, Dec 2019 : 2065 - 2075 
[18] MB. Bayram, I. Sefa, and S. Balci, "A Static Exciter with Interleaved Buck Converter for Synchronous Generators," International Journal of Hydrogen Energy, vol. 42, no. 28, pp. 60-71, 2017.

[19] M. R. Amin, and S. A. Zulkifli, "Modelling of Virtual Synchronous Converter for Grid-Inverter Synchronization in Microgrids Applications," International Journal of Power Electronics and Drive Systems (IJPEDS), vol. 7, no. 4, pp. 1377-1385, 2016.

[20] A. Ausswamaykin, and B. Plangklang, "Design of Real Time Battery Management Unit for PV-Hybrid System by Application of Coulomb Counting Method," Energy and Power Engineering, vol. 6, no. 7, pp. 186-193, 2014.

[21] ZH. Ali, KA. Abdullah, and AT. Saeed, "Modeling Solar Modules Performance Under Temperature and Solar Radiation of Western Iraq," International Journal of Power Electronics and Drive Systems (IJPEDS), vol. 9, no. 4, pp. 1842-1850, 2018.

[22] MF. Zolkifli, MS. Robian, S. Saon, and AK. Mahamad, "FPGA Based Maximum Power Point Tracking of Photovoltaic System Using Anfis Controller (Doctoral dissertation)," Universiti Tun Hussein Onn Malaysia, 2015.

[23] A. Bouhafs, BM. Lokmane, and D. Mohamed, "Grid Connected Photovoltaic System, for a 800 W," Energy Procedia, vol. 74, pp. 414-22, 2015.

[24] L. Hassaine, E. OLias, J. Quintero, and V. Salas, "Overview of Power Inverter Topologies and Control Structures for Grid Connected Photovoltaic Systems," Renewable and Sustainable Energy Reviews, vol. 1, no. 30, pp. 796-807, 2014.

[25] Z. Shao, and KL. Lo, "A Case Study to Determine Optimal Capacity of a Stand-alone wind/PV/battery System," Energy and Power Engineering, vol. 9, no. 4, pp. 300-307, 2017. 